\title{
Head Teachers Supervision Practices and Job Performance of Teachers in Government Aided Secondary Schools in Western Uganda
}

\author{
${ }^{* 1}$ Dinensio K. Zikanga, ${ }^{1}$ Blessing I. Anumaka, PhD, ${ }^{1}$ Maurice B. Tamale, PhD, ${ }^{2}$ Wilson Mugizi, PhD \\ ${ }^{1}$ Kampala International University, Uganda \\ ${ }^{2}$ Kyambogo University, Uganda
}

*Corresponding Mail: dinensio@stud.kiu.ac.ug

\begin{abstract}
The study investigated the relationship between head teachers' supervision practices and job performance of teachers in government aided secondary schools in Western Uganda. Head teachers supervision practices were studied in terms of supervision behavior, support and communication. Job performance of teachers was considered in terms of classroom teaching, management of students, discipline as well as regularity and interpersonal relations. The study adopted a cross-sectional research design using the quantitative approach on a sample of 333 teachers. Data were collected using both the questionnaire. Data were analysed using quantitative. Inferential analysis showed that while supervision behaviors and support had a positive and significant influence on job performance of teachers, supervision communication did not. It was concluded that supervision behaviors and support are important for the job performance of teachers. Therefore, it is recommends that head teachers should provide effective supervision to teachers because such a practice has a significant positive influence on teachers' job performance.
\end{abstract}

Keywords: Behavior, Job performance, Supervision, Support, Communication.

\section{Introduction}

The quality of an education system depends on the quality of its teachers (Mathew, Mathew, \& Peechattu, 2017). Therefore, the key to improving public education is placing effective teachers in classrooms (Darling-Hammond, 2010). Since 1877 when missionaries introduced formal education in Uganda until 1970, a decade after Uganda attained independence in 1962, education was modelled along the British system of education as Uganda was a British protectorate (Namulondo, 2008). During the time, teachers produced excellent performance because they enjoyed good welfare that included housing, medical care and bread and tea during break time (Mazaki, 2017). Nevertheless, the years 1971 to 1979 marked a downturn trend in job performance of teachers because the period was characterized by the turbulence of the regime that affected all sectors of life including teacher's welfare. Since then, job performance of teachers has remained poor, characterized by poor time management, absenteeism, inadequate lesson preparations and syllabus coverage, poor pupil discipline management and inadequate teaching methods (Mujuni, 2019).

To enhance performance of teachers, the government of Uganda has come forward to emphasize supervision in schools. For effective supervision, each school has a head teacher and deputy head teacher charged with direct supervision of teachers. Besides, District/ Municipal council inspectors carry out supervision through inspection of schools. Boards of Governors (BOG) supplement supervision of inspectors while head teachers are responsible for implementing the recommendations of inspectors (Makaaru, Cunningham, Kisaame, Nansozi \& Bogere, 2015). Therefore, every school is supposed to be inspected at least once in two years in national-full inspection. There are also routine-short inspections to monitor new policy priorities implementation and flying visits which are quick inspections to handle emergencies. Follow-up inspection is also carried out to monitor whether recommendations of the 
regular inspections have been implemented or not within 18 months (Hossain, 2017). Despite emphasizing supervision as an intervention measure, performance of teachers has remained poor. In government secondary schools, the dominant feature has been lack of motivation to carry out the job of teaching. About 15 percent of teachers have not been turning up to teach their classes. Teachers report late and have not been effectively executing all their professional duties like making schemes of work, lesson plans and weekly duty. Over the years, poor performance of teachers has been reflected in the dismal performance of students in Uganda National Examinations Board (Mugizi, Mujuni \& Dafiewhare, 2019).

In government aided in the southwestern region where the study was carried out, teaching did not conform to the standards set by the National Curriculum Development Centre [NCDC] and the Directorate of Education Standards [DES] (Zikanga, Anumaka, Tamale \& Mugizi, 2021). Teachers consistently reported late for duty, some teachers hardly appeared at schools and had poor relations with fellow teachers, among others. Many teachers in secondary schools in Uganda hardly prepared schemes of work and lesson plans; and neither conducted sufficient practical lessons or gave time for remedial classes to academically weak students (Malunda, Onen, Musaazi \& Oonyu, 2016). These kinds of pedagogical practices led to poor performance of many students in the national examinations year after year (Zikanga et al., 2021). To address the problem of poor job performance of teachers, this study sought to investigate how head teachers supervision practices related to job performance of teachers in government aided secondary schools in Western Uganda. Basing on Mathieu, Fabi, Lacoursière and Raymond (2016), Eisenberger, Huntington, Hutchison and Sowa (1986) and Johlke and Duhan (2000), supervision was conceived in terms of supervisor behavior, supervisor support and supervisor communication. The study sought to establish the relationship between head teacher's supervision behavior and job performance of teachers, between supervisor support and job performance of teachers and between supervisor communication and job performance of teachers

\section{Literature Review}

This section is a review of related literature and studies which shows the link between head teachers supervision practices and job performance of teachers.

\section{Theoretical Review}

The $X$ and $Y$ Theories propounded by Douglas McGregor in 1957 (Lawter, Kopelman \& Prottas, 2015) guided this study. The $X$ Theory postulates that people are averse to working, lack ambition and a desire for responsibility, are selfish, resistant to change, and gullible (Gannon \& Boguszak, 2013). Hence, the average employee is more efficient under strict supervision (Aithal \& Kumar, 2016). Therefore, the supervision style required for $X$ employees should be the hard approach of the supervisor being coercive, requiring close supervision practices and tight control (Gannon \& Boguszak, 2013). Therefore, there is need for the supervisory behavior that is strict.

On the other hand, the $Y$ Theory postulates that work is as natural as play or rest, and people enjoy working. Therefore, people will exercise selfdirection and self-control in the service of the objectives to which they are committed (Aithal \& Kumar, 2016). Theory $Y$ proposes that the role of management is not simply providing direction but also to organize the employees such that they meet the objectives of the organization (Gannon \& Boguszak, 2013). This theory suggests that supervisors have to employ supervision approaches that are supportive and communicative. Therefore, basing on $X$ theory, the study examined head teachers supervision practices that are supervision behavior, support and communication in relation to job performance of teachers.

\section{Supervision Behavior and Job performance of teachers}

Supervision behaviour ranges from extremely autocratic, with all decision made at the top to the extremely democratic with decision made by employees or subordinates at the lowest level (Weerasuriya \& Nishanthi, 2014). Such behaviors of supervisors can have a significant influence on employees' morale and their work behavior, affecting employees' psychological well-being. Supervisors can be a key influence on what employees experience at work and their work outcomes including performance (Gilbreath \& Karimi, 2012). Scholars (e.g. Aryan \& Singh, 2015; Asmus, Karl, Mohnen \& Reinhar, 2015; Atambo, Kabare, Munene \& Nyamwamu, 2012; Bradler, Dury, Neckermannz \& Non, 2016; Ibok \& Umana, 2013; Teo \& Low, 2016) have carried out studies on 
supervision behavior and employee performance. Aryan and Singh (2015) examined the impact of the supervisor's behavior of recognition on employee's performance using employees of public and private sector banks in Punjab and Haryana in India. Their findings indicated that the supervisor's behavior of recognition had a positive significant influence on performance of the employees.

In their study, Asmus et al. (2015) examined the influence of the supervisor supervision behavior of goal-setting on employee performance in an industrial production process using staff of a training factory for energy productivity in Munich, Germany. The findings revealed that the supervisor's behavior of goal setting improved workers' performance in industrial workplaces. In their study, Atambo et al. (2012) examined the relationship between the supervision behavior of employee recognition and performance with medical services staff drawn from Kenyatta National Hospital as units of analysis. The results revealed that the supervision behavior of recognizing the employee's accomplishments translated into improved performance both at the individual and organizational levels. Further, Bradler et al. (2016) investigated the causal effect of the supervision behavior of employee recognition on employee performance. Their findings indicated that recognition increased subsequent performance substantially, particularly when provided to the best performers.

Using employees of a micro-finance bank in Nigeria, Ibok and Umana (2013) examined the effect of supervisory behavior namely supervisor contingent, supervisor upward influencing behavior, achievement oriented behavior and supervisor arbitrary and punitive behavior sales force performance of the sales force. The findings indicated that all the supervisory behaviors had a statistically positive and significant relationship with performance of the sales force. In their study, Teo and Low (2016) sought to find out whether goal setting had an impact on employee effectiveness and ultimately improving organization effectiveness with employees of a business company on as units of analysis in a high-tech company in Singapore. The results showed that supervisors' goal setting behavior had a positive impact on employee effectiveness. Precisely, the literature above showed that scholars had expended significant effort to investigate the relationship between supervision behavior and employee performance. These findings were consistent with the $Y$ theory which suggests that employees who exhibit interest in work should be treated well to further enhance their performance. However, except for the study by Ibok and Umana (2013), all the other studies obliquely implied supervision behaviors in concepts such as recognition (Aryan \& Singh, 2015; Atambo et al., 2012; Bradler et al. (2016) and goal-setting (Asmus et al., 2015; Teo \& Low, 2016). This study further examined the relationship between supervisors' behaviors and job performance of teachers, considering supervision behaviors on the conception of Mathieu et al. (2016) as referring to person-oriented and task-oriented behaviors.

\section{Supervisor Support and Job Performance of Teachers}

Supervisor support is the employees' views concerning the degree to which their supervisors value their contributions and care about their wellbeing (Mohamed \& Ali, 2016). Frear, Donsbach, Theilgard and Shanock (2018) indicate that based on the norm of reciprocity, enhanced supervisor support makes employees feel obligated to care about the organization's welfare and helps the organisation reach its objectives. Different scholars (e.g. Azman, Sieng, Ajis, Dollah \& Boerhannoeddin, 2009; Miao \& Kim, 2010; Pousa \& Mathieu, 2014; Saleem \& Amin, 2013; Utrilla, Grande \& Lorenzo, 2015) have related supervisor support and employee performance. Azman et al. (2009) measured the effect of the supervisor's role in training programs on job performance using staff of a state library in Sarawak, Malaysia. Using regression, the study established existence of a positive a positive significant relationship between supervisor support and job performance. On their part, Miao and Kim (2010) investigated the correlation between perceived organizational support and employee job performance using employees of state-owned enterprises in China. Their findings indicated a positive correlation between perceived organizational support and employee job performance. In relation to the above, Mohamed and Ali (2015) analysed the relationship between perceived organizational support and employee performance. Accordingly, this was because employees having good perceptions about their employers and viewing their employers as being generally caring about their well-being influence their job performance in a positive way. 
A study done by Okia, Naluwemba and Kasule (2021) in the Eastern Uganda sub region of Teso examined the status of support supervision and performance of primary school teachers. The findings revealed that support supervision offered by head teachers did not significantly enhance performance of teachers. Further Pousa and Mathieu (2014) investigated the influence of supervisor support in terms of employee coaching on employee performance using business-tobusiness salespersons working in Latin America and frontline employees from a service organization in Canada. Their regression findings showed that coaching had a positive and significant influence on performance of employees. Similarly, Saleem and Amin (2013) investigated the impact of supervisory support on employee performance using faculty members of the Universities of Faisalabad in Pakistani as units of analysis. Their results revealed a strong positive and significant relationship between supervisory support and employee performance. Consistent with the above, Utrilla et al. (2015) analysed the effect of the supervisory role of coaching in both employees' development and organizational performance using human resource managers of Spanish firms. Structural modelling results indicated that coaching had an influence on both individual performance and organizational performance. Overall, the literature above concurs with the assumptions of the $Y$ theory which indicates that performance of employees is enhanced if management organizes or supports employees that have positive attitudes to meet the objectives of the organization. However, in the studies above, an empirical gap emerged. This is because while all the other studies indicated existence of a positive significant relationship between supervision support and job performance of teachers, the only study done in Uganda specifically in the Eastern region of the country reported to the contrary. This study was carried out in Western Uganda to establish whether the situation in Uganda was the same or varied in the different regions of Uganda.

\section{Supervisor Communication and Job Performance of Teachers}

Communication is the process of meaning creation with respect to how people create meaning and how messages are understood by the recipients (Van Ruler, 2018). When both the speaker and the recipient understand themselves in a manner that brings engagement, understanding and collaboration rather than mere sending information from one point to the other, then there is effective communication (Smith \& Taylor, 2006). Therefore, effective communication is the process in which intended meaning of what is being said is transmitted in a way that the hearer makes sense of that. It is an engagement process which is bidirectional and not a liner process (Nwagbara et al., 2013). Essentially, relationships grow out of communication, and the functioning and survival of organizations results from effective relationships among individuals and groups. Organizational capabilities are also developed and enacted through intensely social and communicative processes (Jones, Watson, Gardner \& Gallois, 2004; Forzo, 2013).

In their study, Asuquo and Ekpoh (2018) investigated the influence of communication and motivation on teachers' job performance, using a sample of teachers in Calabar Education Zone in Nigeria. Their findings revealed that communication significantly influenced teachers' job performance in public secondary schools. Hee et al. (2019) examined the impact of horizontal communication, downward communication and upward communication that may impact employee performance in a property development company in Malaysia. Their results indicated that communication had a significant positive impact on employee performance. Irad et al. (2020) sought to determine the effect of communication on performance of employees of Hasanuddin University central office in Indonesia. Their analysis established that communication had a positive and significant effect on employee performance. In their study, Moghtader and Aziz (2019) investigated the relationship between communication skills level with job performance of primary school teachers in Urmia in Iran. The results of their analysis indicated existence of a positive and significant relationship between communication skills and teachers' job performance.

In a study seeking to find out the extent to which principals' communication strategies contributed to teachers' work performance in secondary schools, when Nwosu (2017) used teachers in public secondary schools in Ikenne Local Government Area of Ogun State, statistic test results showed that there was a positive significant relationship between principals' communication strategies and teachers' job performance. Saleem and Perveen (2017) studied the impact of formal and informal 
communication in organizations using employees of government and private organizations in GilgitBaltistan, Pakistan. Results indicated that communication had a significant influence on the performance of employees in the organizations. In a study investigating principals' administrative competence and teachers work performance, Owan and Agunwa (2019) used teachers in Calabar Education zone, Nigeria and their findings indicated that the principals' communication competences significantly related to teachers' work performance. However, literature search revealed limited studies on supervisor communication and job performance of teachers in the context of secondary schools in Uganda. This thus attracted the attention of this study in the context of Uganda to further assess the relationship between supervisor communication and job performance of teachers.

\section{Research Methodology}

This section explains the methodology that guided this study. The methodology includes data collection methods, data quality control and analysis methods.

\section{Research Design}

The study adopted the cross-sectional research design involving seeking information on the entire population or a subset of the population selected to help answer research questions of interest. The information collected about the study problem represented what is going on at the time.

\section{Population and Sampling}

The sample comprised 333 teachers from a population of 2741 determined using the Table for determining sample size for a population of a given size by Krejcie and Morgan (1970). The sample was selected using simple random sampling. Using simple random sampling, each individual was chosen by chance basing on the sampling frame containing names of the respondents.

\section{Data Collection Instrument}

Data was collected using a self-administered questionnaire (SAQ). The question items in section $A$ were nominal questions on background characteristics. Sections B through E items were ordinal questions on the dependent variable (job performance of teachers) and independent variable (supervision practices). The items on job performance of teachers (section B) covered four aspects, namely classroom teaching, management of students, discipline and regularity and interpersonal relations performance (Amin, ullah
Shah, Ayaz \& Atta, 2013). The question items on supervision practices were supervisor behaviour (Mathieu, Fabi, Lacoursière \& Raymond, 2016), supervisor support (Eisenberger, Huntington, Hutchison \& Sowa, 1986) and supervisor communication (Johlke \& Duhan, 2000). The items on job performance of teachers and Supervision practices were scaled using the five-point Likert scale from a minimum of 1 for the worst case scenario (strongly disagree) to a maximum of 5 which is the best case scenario (strongly agree).

To ensure data quality, after data collection there was computation of Factor Analysis using the Statistical Package for Social Scientists to establish construct validity of the instruments. Any item that loaded highly, that is above 0.50 was considered valid. However, any item indicating low loading or loading highly more than once was discarded. For reliability, after the collection of data, the reliabilities of the constructs for both the independent and dependent variable were tested using Cronbach's alpha. The Cronbach's alpha results were as follows: job performance of teachers ( $\alpha=0.901)$, supervision behavior $(\alpha=0.826)$, supervisor support $(\alpha=0.842)$ and supervisor communication ( $\alpha=0.884)$. With Cronbach's alphas above the benchmark of 0.70 , the question items in the instrument were considered reliable measures.

\section{Statistical Treatment of Data}

Data processing and analysis were carried out using the Statistical Package for the Social Sciences (SPSS 24.0). Data processing involved summarizing the data using frequency tables to identity errors. The data were then organized, summarized and presented using tables and graphs so that logical and statistical conclusions could be derived. After presentation, the data was screened to identify any potential violation of the basic assumptions related to the application of univariate, bivariate and multivariate techniques. Data analysis was done at descriptive and inferential levels. At descriptive level, means were calculated while at inferential level, correlation and regression analyses were carried out to test the relationship between head teachers supervision practices and job performance of teachers.

\section{Results and Discussion}

This section is a presentation, analysis and interpretation of the results. The results include demographic characteristics of the respondents, descriptive statistics and inferential analyses. 


\section{Demographic Characteristics}

The results in Table 1 reveal that the majority percentage of the respondents was of males (67.9\%) and the females were $32.1 \%$. The larger percentage $(43.8 \%)$ of teachers was of those up to 29 years followed by $34.2 \%$ that were of years between 30 to 39 years. It is also indicated that $16.2 \%$ were between 40 and 49 years and $5.7 \%$ were 50 years and above. The larger percentage (59.2\%) of the teachers had taught for less than 5 years, $28.8 \%$ had taught for 5 to 10 years and $12.0 \%$ had taught for 11 years and above. The larger percentage $(44.7 \%)$ of teachers were subject teachers only, $24.9 \%$ were class teachers, $20.7 \%$ were heads of departments and $9.6 \%$ were senior administrators.

Table 1: Respondents' Background Characteristics

\begin{tabular}{llcc}
\hline Item & Categories & Frequency & Percent \\
\hline Gender & Male & 226 & 67.9 \\
& Female & 107 & 32.1 \\
& Total & 333 & 100.0 \\
\hline Age Groups & Up to 29 years & 146 & 43.8 \\
& $30-39$ years & 114 & 34.2 \\
& $40-49$ years & 54 & 16.2 \\
& 50 years and above & 19 & 5.7 \\
& Total & 333 & 100.0 \\
\hline Education level & Diploma & 112 & 33.6 \\
& Bachelor's degree & 195 & 58.6 \\
& Post graduate diploma & 12 & 3.6 \\
& Master's degree & 14 & 4.2 \\
& Total & 333 & 100.0 \\
\hline Experience & Less than 5 years & 197 & 59.2 \\
& 5 - 10 years & 96 & 28.8 \\
& 11 years and above & 40 & 12.0 \\
& Total & 333 & 100.0 \\
\hline Responsibility & Subject teacher & 149 & 44.7 \\
& Class teacher & 83 & 24.9 \\
& Head of department & 69 & 20.7 \\
& Senior administrator & 32 & 9.6 \\
& Total & 333 & 100.0 \\
\hline
\end{tabular}

Table 2: Job Performance of Teachers

\begin{tabular}{lccc}
\hline Constructs & Mean & Interpretation & Rank \\
\hline Classroom Teaching & 4.34 & High & 4 \\
Management of Students & 4.33 & High & 4 \\
Discipline and Regularity & 4.38 & High & 4 \\
Interpersonal Relations & 4.31 & High & 4 \\
\hline
\end{tabular}

\section{Job Performance of Teachers}

Job performance of teachers was studied as a multidimensional concept describing classroom teaching, management of students, discipline and regularity and interpersonal relations. The measurement scale for the items of the different variables was the five point Likert scale with code 1 as the worst case scenario (strongly disagree) and code 5 the maximum as the best case scenario (Strongly agree). The results were as presented in Table 2 .
The results in Table 2 showed that teachers indicated that their level of job performance was high; that is classroom teaching (mean $=4.34$ ), management of students (mean $=4.33$ ), discipline and regularity (mean $=4.38$ ) and interpersonal relations (mean $=4.31$ ). This is because all means were high close to code 4 which implied agree (high) on the five point Likert scale. 


\section{Supervision practices}

Supervision practices were studied in terms of head teachers supervision behavior, supervisor support and supervisor communication. The measurement scale for the items of the different variables was the five point Likert scale with code 1 as the worst case scenario (strongly disagree or very poor) and code 5 the maximum as the best case scenario (Strongly agree or very good). The results on the same were as presented in Table 3.

The results in Table 3 showed that teachers rated the supervision practices of their head teachers as good that is supervision behavior (mean $=4.21$ ), support (mean = 3.94), and supervisor communication (mean $=4.00$ ). This is because all means were high close to code 4 that implied agree (high) on the five point Likert scale.

Table 3: Supervision practices

\begin{tabular}{llll}
\hline Constructs & Mean & Interpretation & Rank \\
\hline Supervision Behavior & 4.21 & Good & 4 \\
Supervisor Support & 3.94 & Good & 4 \\
Supervisor Communication & 4.00 & Good & 4 \\
\hline
\end{tabular}

Table 4: Correlation between Supervision Practices and Job Performance of Teachers

\begin{tabular}{|c|c|c|c|c|}
\hline & $\begin{array}{l}\text { Job } \\
\text { Performance of } \\
\text { Teachers }\end{array}$ & $\begin{array}{l}\text { Supervision } \\
\text { practices } \\
\text { Behavior }\end{array}$ & $\begin{array}{l}\text { Supervisor } \\
\text { Support }\end{array}$ & $\begin{array}{l}\text { Supervisor } \\
\text { Communication }\end{array}$ \\
\hline Job Performance of & 1 & $0.482^{* *}$ & $0.402^{* *}$ & $0.363^{* *}$ \\
\hline Teachers & & 0.000 & 0.000 & 0.000 \\
\hline \multirow[t]{2}{*}{ Supervision Behavior } & & 1 & $0.568^{* *}$ & $0.594^{* *}$ \\
\hline & & & 0.000 & 0.000 \\
\hline \multirow[t]{2}{*}{ Supervisor Support } & & & 1 & $0.452^{* *}$ \\
\hline & & & & 0.000 \\
\hline Supervisor & & & & 1 \\
\hline Communication & & & & \\
\hline
\end{tabular}

Table 5: Regression of Job Performance of Teachers on Supervision Practices

\begin{tabular}{lcc}
\hline Supervision practices & $\begin{array}{c}\text { Standardised Coefficients } \\
(\beta)\end{array}$ & $\begin{array}{c}\text { Significance } \\
(\mathrm{p})\end{array}$ \\
\hline Supervisor Supervision Behaviour & 0.410 & 0.000 \\
Supervisor support & 0.165 & 0.048 \\
Supervisor Communication & & 0.575 \\
& -0.050 & \\
$\mathrm{R}^{2}=0.239$ & & \\
Adjusted $\mathrm{R}^{2}=0.231$ & & \\
$\mathrm{~F}=28.998, \mathrm{p}=0.000$ & & \\
\hline
\end{tabular}

Correlation of Supervision practices and Job Performance of Teachers

To establish the extent of the relationship between supervision practices and job performance of teachers, at a preliminary level, a correlation analysis test was carried out. The results were as presented in Table 4.

The correlation results in Table 4 revealed that all supervision practices that are namely; supervision behavior $(r=0.482, p=0.000<0.05)$, support $(r=$ $0.402, p=0.000<0.05)$ and communication $(r=$ $0.363, p=0.000<0.05$ ) had a positive significant relationship with job performance of teachers. However, the relationship between head teachers supervision practices and job performance of teachers was moderate as suggested by Ratner (2009) that correlation coefficient values between 0.3 and 0.7 indicate a moderate positive linear relationship.

\section{Regression of Job Performance of Teachers on Supervision practices}

At the confirmatory level, to establish whether supervision practices namely; supervisor behaviour, support and communication influenced job performance of teachers, a regression analysis was carried out. The results were as in Table 5. 
At the confirmatory level, to establish whether supervision practices namely; supervisor behavior, support and communication influenced job performance of teachers, a regression analysis was carried out. Regression analysis involved testing the hypotheses whether there is a significant relationship between head teacher's supervision behavior and job performance of teachers, between supervisor support and job performance of teachers and between supervisor communication and job performance of teachers. The results were as in Table 5.

Table 5 shows that supervision practices (supervisor behavior, support and communication) explained $23.9 \%$ of the variation in job performance of teachers $\left(R^{2}=0.231\right)$. This means that $76.1 \%$ of the variation in job performance of teachers was accounted for by other factors not considered under this model. However, only two supervision practices namely; supervision practices behavior $(\beta=0.410, p$ $=0.000<0.05)$ and support $(\beta=0.165, p=0.005<$ 0.05 ) had a positive and significant influence on job performance of teachers. These significant supervision practices explained $23.1 \%$ of the variation in job performance of teachers (Adjusted $R^{2}=0.231$ ). On the other hand, supervisor communication $(\beta=-0.050, p=0.575<0.05)$ had a negative insignificant influence on job performance of teachers. The magnitudes of the respective data suggested that supervisor supervision practices behavior had more significant influence on job performance of teachers followed by supervisor support.

\section{Discussion}

The findings revealed that supervision behavior had a positive significant relationship with job performance of teachers. This finding is consistent with the findings made by previous scholars. For instance, Aryan (2015) revealed that the supervisor's behaviour of recognition had a positive significant influence on performance of the employees. Similarly, Asmus et al. (2015) found out that the supervisor's behavior of goal setting improved workers' performance in industrial workplaces. Likewise, Atambo et al. (2012) reported that the supervision behavior of recognizing the employee's accomplishments translated into improved performance both at the individual and organizational levels. Consistent with the above, Bradler et al. (2016) reported that the behaviors of recognition increased subsequent performance substantially and particularly so when recognition was exclusively provided to the best performers. Also, Ibok and Umana (2013) revealed that all the supervisory behavior had a statistically positive and significant relationship with performance of the sales force. Teo and Low (2016) also concurred that the head teachers' goal setting behavior had a positive impact on employee effectiveness.

The findings of the study also revealed that supervisor support had a positive and significant relationship with job performance of teachers. This finding agreed with the findings of previous scholars. For example, Azman et al. (2009) established a positive significant relationship between supervisor support and job performance. Likewise, Miao and Kim (2010) reported a positive correlation between perceived organizational support and employee job performance. Also, Mohamed and Ali (2015) revealed that employees having good perceptions about their employers and viewing their employers as being generally caring about their well-being influence their job performance in a positive way. Pousa and Mathieu (2014) also reported that supervisor support had a positive and significant influence on performance of employees. Further, in agreement with study Saleem and Amin (2013) revealed that there is a strong positive and significant relationship between supervisory support and employee performance. In the same vein, Utrilla et al. (2015) found out that supervisor support had an influence on both individual performance and organizational performance.

Nevertheless, the findings indicated that supervisor communication had a negative and insignificant influence on job performance of teachers. However, this finding is inconsistent with the findings of previous scholars. For instance, the previous study by Asuquo and Ekpoh (2018) revealed that communication significantly influenced teachers' job performance in public secondary schools. Similarly, Irad et al. (2020) established that communication had a positive and significant effect on employee performance. Further still, Moghtader and Aziz (2019) indicated existence of a positive and significant relationship between communication skills with teachers' job performance. Likewise, Nwosu (2017) showed that there was positive significant relationship between principals' communication strategies and teachers' job performance. Also, Owan and Agunwa (2019) revealed that the principals' communication competences significantly related to teachers' work 
performance. The discussion above suggests that the finding of this study did not concur with the findings of previous scholars. Therefore, it was deduced that in the context of government aided secondary schools in Western Uganda, supervisor communication was not of significance as far as job performance of teachers was concerned.

\section{Conclusions and Recommendations}

This study concluded that supervision behaviors of head teachers are important for job performance of teachers. This is especially when head teachers involve goals setting, standards setting, performance recognition and respectfulness. Supervision support is a prerequisite for job performance of teachers. This is so when head teachers provide a motivating environment, offer coaching to teachers, give direction and decentralize activities. This study recommends that head teachers should provide effective supervision to teachers to ensure good job performance. This should involve head teachers developing the supervision behavior of setting goals and standards for teachers, offering performance recognition and respecting teachers during supervision. Head teachers should also be supportive by providing teachers a motivating environment, offering coaching, giving direction and decentralising activities such that there is participatory management. The limitation of this study is that the findings on supervisor communication contradicted the findings made by previous studies by indicating that it was not a significant predictor of job performance of teachers. This finding calls for further research on a country wide scale to clarify the importance of the same variable in predicting job performance of teachers in secondary schools in Uganda. Furthermore, this study was carried out in government aided secondary schools only. This suggests that the generalisation of the research findings to private schools should be considered with care. Therefore, future studies should make effort to carry similar or related studies in private secondary schools.

\section{References}

Aithal, P. S., \& Kumar, P. M. (2016). Organisational behaviour in 21st century - 'Theory A' for managing people for performance. IOSR Journal of Business and Management (IOSRJBM), 18(7), 126-134. http://dx.doi.org/10.2 $139 /$ ssrn.2816887.
Amin, M., ullah Shah, R., Ayaz, M., \& Atta, M. A. (2013). Teachers' job performance at secondary level in Khyber Pakhyunkhwa, Pakistan. Gomal University Journal of Research, 29(2), 101- 104

Aryan, R., \& Singh, A. (2015). Impact of motivation and recognition on employee performance: a study on public and private sector banks in Punjab and Haryana. Global Journal of Management and Business Research, 15(13), 1-6.

Asmus, S., Karl, F., Mohnen, A., \& Reinhart, G. (2015). The impact of goal-setting on worker performance-empirical evidence from a real-effort production experiment. Procedia CIRP, 26, 127-132. doi: 10.1016/j.proc ir.2015.02.086.

Asuquo, M. E., \& Ekpoh, U. I. (2018). Leadership variables and teachers' job performance in public secondary schools in Calabar Education Zone of Cross River State. Prestige Journal of Counselling Psychology, 1(1), 25-35.

Atambo, W. N., Munene, C., \& Mayogi, E. N. (2013). The role of employee incentives on performance: a survey of public hospitals in Kenya. International Journal of Arts and Commerce 1(7), 95-109.

Azman, I., Sieng, L. L. C., Ajis, M. N. E., Dollah, N. F., \& Boerhannoeddin, A. (2009). Relationship between supervisor's role and job performance in the workplace training program. Analele Stiintifice ale Universitatii" Alexandru loan Cuza" din lasi-Stiinte Economice, 56, 237-251.

Bradler, C., Dur, R., Neckermann, S., \& Non, A. (2016). Employee recognition and performance: A field experiment. ZEWCentre for European Economic Research Discussion Paper, (13-017).

Darling-Hammond L (2010). Evaluating teacher effectiveness: How teacher performance assessments can measure and improve teaching. Report by Centre for American Progress. Retrieved from https://www.am 
eric anprogress.org/.../education-k.../evalu atingteacher-effectiveness/.

Eisenberger, R., Huntington, R., Hutchison, S., \& Sowa, D. (1986). Perceived organizational support. Journal of Applied psychology, 71(3), 500-507. https://doi.org /10.103 7/0021-9010.71.3.500.

Forzo, T. F. (2013). The impact of internal communication on employee performance in an organization. Available at: http://dx.doi.o rg/10.2139/ssrn.2865675.

Frear, K. A., Donsbach, J., Theilgard, N., \& Shanock, L. R. (2018). Supported supervisors are more supportive, but why? A multilevel study of mechanisms and outcomes. Journal of Business and Psychology, 33(1),55-69. https://doi.org/10.1007/s10869-016-94852 .

Gannon, D., \& Boguszak, A. (2013). Douglas Mcgregor'S Theory X And Theory Y. CRISBulletin of the Centre for Research and Interdisciplinary Study, 2013(2), 85-93. https://doi.org/10.2478/cris-2013-0012 (text/html).

Gilbreath, B., \& Karimi, L. (2012). Supervisor supervision behaviour and employee presenteeism. International Journal of Leadership Studies, 7(1), 114-131.

Hee, O. C., Qin, D. A. H., Kowang, T. O., Husin, M. M., \& Ping, L. L. (2019). Exploring the impact of communication on employee performance. International Journal of Recent Technology and Engineering, 8(3), 654-658. doi:10.35940/ijrte. c1213.108 3 s219.

Hossain, M. (2017). School inspection challenges: Evidence from six countries. Background paper prepared for the 2017/8 Global Education Monitoring Report.

lbok, N, I., \& Umana, V. S. (2013). Impact of supervisory behaviours on sales force performance: The case of micro finance banks. Journal of Economics and Sustainable Development, 4(3), 118-124.

Irad, H., Muis, M., \& Rasjid, W. (2020). The effect of communication on employee performance at center office of Hasanuddin University with motivation as intervening variables. Hasanuddin Journal of Applied Business and Entrepreneurship, 3(2), 11-19. doi: https://doi.org/10.26487/hjabe.v3i2.31 5 .

Johlke, M. C., \& Duhan, D. F. (2000). Supervisor communication practices and service employee job outcomes. Journal of Service Research, 3(2), 154-165. https://doi.org/10. 1177/ 109467050032004.

Jones, E., Watson, B., Gardner, J., \& Gallois, C. (2004). Organisational communication: Challenges for the new century. Journal of Communication, 54(4), 722-750.

Krejcie, R. V., \& Morgan, D. W. (1970). Determining sample size for research activities. Educational and Psychological Measurement, 30, 607-610.

Lawter, L., Kopelman, R. E., \& Prottas, D. J. (2015). McGregor's Theory $X / Y$ and Job Performance: A Multilevel, Multi-source Analysis. Journal of Managerial Issues, 27(1/4), 84-101. http://www.jstor .org/ stable/44113685.

Makaaru, J., Cunningham, K., Kisaame, K., Nansozi, S., and Bogere, G., (2015). Public expenditure governance in uganda's education sector: Application of an innovative assessment framework, Kampala. ACODE Policy Research Series, No. 67.

Malunda, P., Onen, D., Musaazi, J., \& Oonyu, J. (2016). Instructional supervision and the pedagogical practices of secondary school teachers in Uganda. Journal of Education and Practice, $7(30), 177-187$.

Mathew, P., Mathew, P., \& Peechattu, P. J. (2017). Reflective practices: A means to teacher development. Asia Pacific Journal of Contemporary Education and Communication Technology, 3(1), 126-131.

Mathieu, C., Fabi, B., Lacoursiere, R., \& Raymond, L. (2016). The role of supervisory behavior, job satisfaction and organizational commitment on employee turnover.Journal of Management \& Organization, 22(1), 113129. doi: https://doi.org/10.1017/jm 0.201 5.25 .

Mazaki, K. E. (2017). Staff welfare and teachers 'performance in public primary schools in 
Bugisu Sub-Region in Uganda (PhD Dissertation, Mbarara University of Science And Technology). Mbarara, Uganda.

Miao, R., \& Kim, H. G. (2010). Perceived organizational support, job satisfaction and employee performance: An Chinese empirical study. Journal of Service Science and Management, 3(02), 257-264.

Moghtader, H., \& Aziz, R. G. G. (2019). The relationship between communication skills and managers 'thinking style functions with the job performance of elementary school teachers in Urmia, Iran in the academic year 2018-2019. European Journal of Education Studies, 6(5), 103-116.

Mohamed, S. A., \& Ali, M. (2016). The importance of supervisor support for employees' affective commitment: An analysis of job satisfaction. International Journal of Scientific and Research Publications, 6(2), 435-439.

Mugizi, W., Mujuni, B. T., \& Dafiewhare, O. A. (2019). Ethical leadership and job performance of teachers in secondary schools in Kyabugimbi Sub-County in Bushenyi District in Southwestern Uganda. Direct Research Journal of Education and Vocational Studies, 1(1), 11-22. doi: https://doi.org/10.5281/zenodo. 3497120.

Mujuni, B. (2019). Ethical leadership and job performance of teachers in secondary schools in Kyabugimbi Sub-County, Bushenyi District, Uganda (Masters Dissertation, Kampala International University). Kampala, Uganda.

Namulondo, T. (2008). The secret behind the figures: Evaluation of UPE program in Iganga District (Masters Dissertation, Institute of Social Studies, The Hague, The Netherlands).

Nwagbara, U., Smart Oruh, E., Ugorji, C., \& Ennsra, M. (2013). The impact of effective communication on employee turnover intension at First Bank of Nigeria. Economic Insights-Trends \& Challenges, 65(4), 75-85.

Nwosu, J. C. (2017). Principals' communication strategies and teachers' job performance in public secondary schools in Ikenne Local
Government Area of Ogun State. International Journal of Education, Learning and Development, 5(9), 1-12.

Okia, H. S., Naluwemba, E. F., \& Kasule, G. W. (2021). Status of support supervision and performance of primary school teachers in Uganda: A qualitative perspective. International Journal of Education and Social Science Research, 4(3), 115-134. doi: http://dx.doi.org/10.37500/IJESSR.2021.431 0 .

Owan, V. J., \& Agunwa, J. N. (2019). Principals' administrative competence and teachers' work performance in secondary schools in Calabar Education Zone of Cross River State, Nigeria. Online Submission, 7(1), 20-28. doi: 10.18488/journal.73.2019.71.20.28

Pousa, C., \& Mathieu, A. (2014). The influence of coaching on employee performance: Results from two international quantitative studies. Performance Improvement Quarterly, 27(3), 75-92. https://doi.org/ $10.1002 /$ piq. 21175

Ratner, B. (2009). The correlation coefficient: Its values range between $+1 /-1$, or do they? Journal of Targeting, Measurement and Analysis for Marketing, 17(2), 139-142. doi:10.1057/jt.2009.5.

Saleem, M., \& Perveen, N. (2017). The Impact of Formal and Informal Communication in Organizations a Case Study of Government and Private Organizations in GilgitBaltistan. Journal of Business and Management Sciences. 5(4), 139-144. doi:10.12691/jbms-5-4-5.

Saleem, S., \& Amin, S. (2013). The impact of organisational support for career development and supervisory support on employee performance: An empirical study from Pakistani academic sector. European Journal of Business and Management, 5(5), 194-207.

Smith, P. R., \& Taylor, J. (2006). Marketing communication: An integrated approach. London, UK: Kogan Page.

Teo, T. C., \& Low, K. C. P. (2016). The impact of goal setting on employee effectiveness to improve organisation effectiveness: Empirical study of a high-tech company in

64 East African Journal of Education and Social Sciences (EAJESS) 2(4)54-65 
Singapore. Journal of Business \& Economic Policy, 3(1), 82-97.

Utrilla, P. N. C., Grande, F. A., \& Lorenzo, D. (2015). The effects of coaching in employees and organizational performance: The Spanish Case. Intangible Capital, 11(2), 166-189.

Van Ruler, B. (2018). Communication theory: An underrated pillar on which strategic communication rests. International Journal of Strategic Communication, 12(4), 367-381. https://doi.org/10.1080/1553118X.2018.14 52240.
Weerasuriya, M. K., \& Nishanthi, H. M. (2014). Impact of supervisory leadership style on employee level of stress in Sri Lankan healthcare sector. International Conference on Business and Information (ICBI), Faculty of Commerce and Management Studies, University of Kelaniya, Sri Lanka.

Zikanga, S. K., Anumaka, B. I., Tamale, M. B., \& Mugizi, W. (2021). Remuneration and job performance of teachers in government aided secondary schools in Western Uganda. Interdisciplinary Journal of Education Research, 3(2), 10-22. https://doi. org/10.51986/ijer-2021.vol3.02.02 